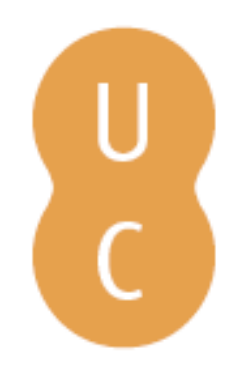

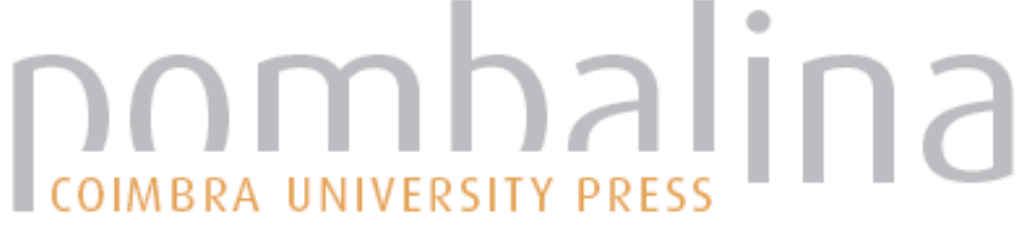

\section{Plutarco: o regresso a terras Itálicas}

\author{
Autor(es): $\quad$ Marnoto, Rita \\ Publicado por: Imprensa da Universidade de Coimbra \\ URL \\ persistente: URI:http://hdl.handle.net/10316.2/30744 \\ DOI: $\quad$ DOI:http://dx.doi.org/10.14195/978-989-8281-94-4_2
}

Accessed : $\quad$ 26-Apr-2023 14:21:47

A navegação consulta e descarregamento dos títulos inseridos nas Bibliotecas Digitais UC Digitalis, UC Pombalina e UC Impactum, pressupõem a aceitação plena e sem reservas dos Termos e Condições de Uso destas Bibliotecas Digitais, disponíveis em https://digitalis.uc.pt/pt-pt/termos.

Conforme exposto nos referidos Termos e Condições de Uso, o descarregamento de títulos de acesso restrito requer uma licença válida de autorização devendo o utilizador aceder ao(s) documento(s) a partir de um endereço de IP da instituição detentora da supramencionada licença.

Ao utilizador é apenas permitido o descarregamento para uso pessoal, pelo que o emprego do(s) título(s) descarregado(s) para outro fim, designadamente comercial, carece de autorização do respetivo autor ou editor da obra.

Na medida em que todas as obras da UC Digitalis se encontram protegidas pelo Código do Direito de Autor e Direitos Conexos e demais legislação aplicável, toda a cópia, parcial ou total, deste documento, nos casos em que é legalmente admitida, deverá conter ou fazer-se acompanhar por este aviso.

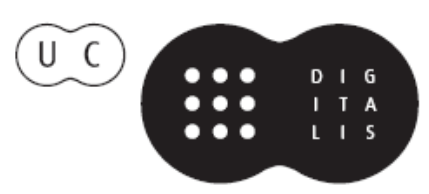




\section{Joaquim Pinheiro José Ribeiro Ferreira Nair Castro Soares Rita Marnoto}

Caminhos de Plutarco na EUROPA

$2^{a}$ EDIÇÃo REVISTA E AUMENTADA 


\section{Plutarco: O Regresso a terras itálicas}

Rita Marnoto

(Universidade de Coimbra)

A obra do Educador da Europa teve uma projecção vastíssima, na literatura italiana, ao longo de um percurso que se estende desde o século XIV aos nossos dias. Se a Península Itálica desempenhou uma funçãochave, pelo que diz respeito à recuperação moderna dos seus escritos, Plutarco é uma referência constante nas suas letras.

1. O papel da cultura italiana, enquanto fundamental via intermediária através da qual foi recuperado Plutarco, só poderá ser cabalmente compreendido tomando em linha de conta a continuidade dos elos que, ao longo da Idade Média, sempre foi mantendo com o mundo grego. É na esteira de um relacionamento que se alarga a campos muito diversos (de natureza comercial, administrativa, linguística ou religiosa) que o interesse pelo helenismo continua vivo, pontualmente, em alguns centros onde a língua grega é estudada e certos textos nela escritos são objecto de tradução. ${ }^{1}$

${ }^{1}$ Este quadro geral foi sintetizado por R. Weiss em alguns dos estudos reunidos em Medieval and Humanist Greek, com relevo para: "I. Greek in Western Europe at the End of the Middle Ages", "II. The Greek Culture of South Italy in the Later Middle Ages", "VIII. The Translators from the Greek of the Angevin Court of Naples", "XIII. Per la storia degli studi greci alla curia papale nel tardo Duecento e nel Trecento". 
No Sul de Itália, na Calábria, na Apúlia e na Sicília, os rituais da Igreja continuavam a seguir a prática grega. Era significativo o número de falantes de grego dessas zonas da Península, sendo, aliás, a linguagem quotidiana de comunicação herdeira próxima do grego clássico. ${ }^{2} \mathrm{Os}$ monges de S. Basílio de Cesareia de Capadócia tiveram um papel importantíssimo, ao longo de toda a Idade Média, na vida intelectual dessas regióes. Nas suas bibliotecas, encontravam-se guardados não só textos de índole religiosa, bem como de autores profanos (Aristófanes, Platão, Euclides, Homero, Galeno), também eles objecto de estudo. A actividade translativa de grego para latim encontra-se já documentada no século XII, recebendo grandes incentivos ao tempo do imperador Frederico II de Hohenstaufen e de seu filho Manfredi, que dominaram o Sul de Itália até 1266, data do recontro de Benevento. Nas suas chancelarias, notários latinos e sarracenos ombreavam com notários gregos. Quando a casa de Anjou assume o governo da Itália meridional, o interesse pela cultura grega de forma alguma decresce. Apesar de Carlos I não ter manifestado qualquer tipo de apreço pela produção dos poetas em vulgar que haviam circulado na órbita da Magna curia, formando a célebre "escola siciliana", o labor translativo continua a ser estimulado. Para além da teologia e da filosofia, são privilegiadas áreas ligadas

${ }^{2}$ Tal como o continuam a ser, na actualidade, os dialectos dessas zonas de Itália, pese embora uma evolução diacrónica que implicou, além do mais, a sobreposição de novos estratos linguísticos. Para uma perspectiva global desta questáo, vide: M. A. Cortelazzo 1984; Tulio De Mauro 1999; G. Devoto, G. Giacomelli 2002; Rohlfs 1969. 
ao saber prático, com relevo para a medicina e para as ciências naturais, ao mesmo tempo que é incrementada a busca de textos gregos. Foi também nesse período que, em nome das boas relaçóes entre a casa de Anjou e o papado, um bom número de códices gregos passou para as estantes da biblioteca da Cúria romana, onde veio a despertar a curiosidade de muitos humanistas. ${ }^{3}$ Outro foi o trágico destino do rico acervo napolitano, que ficou irremediavelmente sepultado nas águas do Adriático quando, na sequência da invasão de Luís da Hungria, em 1347-48, a embarcação que carregava tão portentoso saque sofreu um terrível naufrágio.

$\mathrm{Na}$ Cúria papal, a língua e a cultura gregas suscitavam um interesse muito particular, o qual, além de responder a exigências de ordem litúrgica, se encontrava intimamente ligado à necessidade de manter permanentes relaçóes com o mundo bizantino, em especial com a Igreja Grega, designadamente ao longo daquele período em que questão da união das duas Igrejas era um assunto de primordial importância. Tornava-se indispensável, pois, a constante disponibilidade de um corpo de intérpretes, embaixadores e missionários que dominasse a língua. No entanto, o grego que se estudava na Cúria, nos séculos XIII e XIV, não seria o grego

${ }^{3}$ Sinal da proximidade entre a casa de Anjou e o Vaticano, ao tempo do papa Clemente IV. Todavia, essa proximidade veio a revelar-se, da mesma feita, um obstáculo à união das duas Igrejas, quando Martinho IV excomunga Miguel VIII Paleólogo em 1281, na mira de deixar aberto um espaço susceptível de facilitar a conquista do Império bizantino por Carlos I de Anjou (cf. R. Weiss 1977: 194-195). 
clássico, mas, prevalentemente, o grego de Bizâncio e dos teólogos da Igreja Ortodoxa. Apesar disso, é num ambiente caracterizado por uma certa abertura ao mundo helénico que se enquadra a passagem pela Cúria de personalidades que deram um importante contributo ao incentivo do estudo do grego, como S. Tomás de Aquino e o seu colaborador Moerbeke, que traduziu numerosos textos a seu pedido. Aliás, não foram apenas os Dominicanos a apoiarem essa área do saber, pois também uma outra voz de grande influência nos meios romanos, Raimon Lull, corroborou a mesma posição. Não se possuem muitas informaçóes acerca do ensino do grego na Cúria, embora se saiba que era praticado, mas à margem de objectivos especificamente literários. Nesse quadro, emerge o nome de Barlaam Calabro. Monge de S. Basílio, Barlaam colaborara com os Anjou no sentido de organizar a secção helénica da sua biblioteca. Em 1339, encontra-se em Avinhão com uma missão diplomática e, em 1342, ensina grego na mesma cidade. A sua nomeação como Bispo de Gerace, a 2 de Outubro do mesmo ano, leva-o, porém, a abandonar a Cúria. O seu nome ficou célebre pelo facto de, entre os seus discípulos, se contar o "primeiro moderno", Francesco Petrarca ${ }^{4}$. Talvez trouxesse consigo o monge bizantino Símone Atumano, que encontramos de novo em Avinhão em 1363 (quando dá lições de grego a

${ }^{4}$ Sobre o conhecimento, pela parte de Petrarca, de Homero e da cultura grega, vide: ibid., cap. "X. Per la storia degli studi greci del Petrarca: il Triglossos", "XI. Notes on Petrarch and Homer", "XII. Petrarca e il mondo greco"; e Guido Martellotti, M. Feo 1983: 579-592 
Francesco Bruni) e, posteriormente, a partir de 1372, tendo-se transferido para Roma ao tempo de Urbano VI. Foi através da pena de Atumano que o Ocidente conheceu alguns dos primeiros textos de Plutarco. Mas já voltaremos à figura de Atumano.

Pelo que diz respeito às relaçóes comerciais com o mundo grego durante os últimos séculos da Idade Média, merecem destaque dois grandes centros do comércio mediterrânico, a República Veneziana e Florença. O vínculo que liga Veneza ao Império Romano do Oriente remonta ao século VI. Perante as dificuldades em fazer face à invasão lombarda, os venezianos solicitaram a protecção do Imperador, através do Exarco de Ravena, donde resultou uma situação de dependência da qual a Serenissima, nos séculos sucessivos, saberá tirar o melhor proveito em termos comerciais. Se bem que esse tipo de relacionamento não se traduzisse então, necessariamente, num efectivo interesse pela cultura e pela literatura gregas, facto é que, ao longo de todo o século $\mathrm{XV}$, Veneza será um dos mercados da Europa ocidental onde a aquisição de códices gregos é mais fácil. Por sua vez, a Universidade de Pádua era tradicionalmente frequentada por uma colónia de estudantes gregos, muitos dos quais cipriotas. Ao saber da presença, por aquelas paragens, de Leonzio Pilato, um calabrês aluno de Barlaam que, para elevar o seu coturno, se dizia oriundo de Salónica, ${ }^{5}$ Petrarca chama-o à sua residência paduana $^{6} e$, graças ao entusiasmo e às influências

${ }^{5}$ Cf. G. Billanovich 1947: 245-250.

${ }^{6}$ Petrarca possuía já o precioso códice de Homero que entrou 
movidas por Boccaccio, leva-o a aceitar a cátedra que lhe era oferecida pela Universidade de Florença. O autor da Genealogia deorum gentilium mantinha desde a sua juventude, passada na florescente corte napolitana dos Anjou, uma viva curiosidade pela língua grega, que nunca tivera verdadeira oportunidade de satisfazer. No Outono de 1360, o Calabrês dava início às suas liçôes de grego com base no texto de Homero, destinadas a uma ilustre plateia onde se integravam Giovanni Boccaccio, Domenico Silvestri e o franciscano Tedaldo della Casa. Mas a instabilidade e o espírito aventureiro que lhe eram próprios impediram-no de dar continuidade à leccionação. Em 1362, abandona Florença.

Desta feita, entre os pequenos núcleos da Península itálica onde o estudo do grego se fora mantendo vivo ao longo da Idade Média, vão começando a ser estabelecidos tímidos contactos, relativos à circulação de manuscritos e ao ensino da língua, que se processam, obviamente, no âmbito do inerente contexto epocal. Todavia, assim se vai delineando uma rede de linhas que se estende entre o Nordeste da Península e Florença, com estritas ligaçóes à Cúria papal, para se prolongar pelo Sul. É sintomático, pois, que na sua configuração fique esboçado o sistema

na sua biblioteca entre finais de 1353 e inícios do ano seguinte. Segundo U. Dotti 2004:192, tê-lo-ia adquirido através do bizantino Nicolau Sigero, personagem de grande cultura que conheceu em Verona nos primeiros meses de 1348, quando esse alto dignitário se dirigia para Avinháo, e com o qual logo estabeleceu uma amizade intelectual. Sobre a metodologia de Pilato, vide G. Martellotti 1983: 241-248, "Osservazioni sul carattere orale del primo insegnamento del greco nell'Italia umanistica”. 
de eixos de intersecção que marcará a geografia da literatura italiana do período renascentista - que é também dizer, a descoberta de Plutarco.

2. Posto isto, vejamos qual o lugar que cabe à obra do "Educador da Europa" neste quadro de relaçóes. No âmbito da actividade de translação incentivada pelos normandos, o seu nome é citado pelo tradutor do Fédon, Enrico Aristipo, ${ }^{7}$ no respectivo prefácio, em 1156. Não obstante, segundo Weiss, para o homem medieval Plutarco foi pouco mais do que um puro nome. ${ }^{8} \mathrm{O}$ proveito que Petrarca e Boccaccio tiraram das liçóes de Barlaam e de Pilato foi escasso, embora o esforço de aproximação à cultura helénica levado a cabo por estes intelectuais seja muito significativo. $\mathrm{Na}$ verdade, ficaram rasgadas vias que haviam de conduzir à implantação de grandes centros de estudo do grego e que constituíram, da mesma feita, pólos de referência basilares do Humanismo europeu. Recorde-se que "o

${ }^{7}$ Nos últimos anos, o mérito da actividade translativa levada a cabo por Aristipo tem vindo a ser posto em evidência, enquanto ponte mediadora através da qual a Idade Média latina teve acesso a muitos textos gregos e árabes. Traduziu o Ménon e o Fédon de Platão (a sua versão do Fédon serviu de referência às várias geraçóes de humanistas que vão de Petrarca a Salutati), o quarto livro dos Meteorologica de Aristóteles, e, muito possivelmente, Diógenes Laércio e Gregório de Nazianzo. Vide E. Franceschini 1962: 201-206.

${ }^{8}$ Cf. R. Weiss 1977: 205 e passim, onde também se colhem detalhadas informaçóes acerca das primeiras traduçóes e vulgarizamentos de Plutarco. Esclareça-se que, relativamente à época em causa, quando falamos em tradução nos referimos à versão de grego para latim, ao passo que a translação para a linguagem vulgar será designada como vulgarizamento. 
primeiro moderno" apenas conhecia Plutarco através de Aulo Gélio, e uma das notícias mais exactas que sobre ele possuía era a de que escrevera um tratado sobre a ira, De cohibenda ira, como resulta da epístola Familiaris 12.3.3. Para além disso, fica o legendário autor do apócrifo De institutione principum que Petrarca teria conhecido através do Policraticus de John of Salisbury. Apesar de esta situação nada ter de extraordinário, visto não implicar substanciais alteraçôes em relação ao horizonte de conhecimento do intelectual da Idade Média, não deixa de ser sintomático o facto de a primeira obra de Plutarco que o mundo ocidental viu traduzida ser esse mesmo tratado cuja existência fora assinalada pelo "primeiro moderno" - De ira.

Teria sido no ambiente da corte papal de Avinhão que os contornos da personalidade do "Educador da Europa" começaram a ganhar alguma nitidez. Foi tradutor do De ira aquele Símone Atumano que circulava pela Cúria na sombra de Barlaam. Teria sido também ele próprio a accionar os meios necessários para fazer chegar o original grego a Avinhão. Conforme consta da carta dedicatória datada de 20 de Janeiro de 1373, pôs mãos à empresa a instâncias do cardeal Pietro Corsini, uma interessante personagem da Cúria avinhonense dotada de vastíssimos e surpreendentes interesses culturais. É, da mesma forma, no círculo de literatos de Avinhão que surge uma outra versão de Plutarco, desta feita um conjunto de biografias que tem a particularidade de ser registado em aragonês. No centro de uma longa cadeia de relaçôes, encontra-se um catalão, Juan Fernández de 
Heredia, nomeado governador de Avinhão por Inocêncio VI em 1356, e depois eleito, em 1377, Grão-Mestre da Ordem do Hospital de S. João, então sediada em Rodes. A sua curiosidade pela obra de Plutarco levou-o a trazer dessa cidade uma versão do referido texto em grego moderno, lavrada pela pena de Demétrio Calódicos. Posteriormente, esse texto foi traduzido para aragonês em Avinhão, por Nicolau, Bispo de Drenopla (antiga Adrianopla, na Etólia), em data que tem por termo ante quem o ano de 1388. Ambas as versôes logo desfrutaram de uma larga difusão europeia.

Este episódio encerra o capítulo relativo à circulação medieval de Plutarco, ao mesmo tempo que rasga as vias conducentes à interpretação da sua obra sob uma nova luz. De facto, Weiss ${ }^{9}$ considera que o conhecimento de Plutarco não se distanciara ainda, nessa fase, da forma como a Idade Média lia os clássicos em sentido instrumental, ou seja, em função de objectivos utilitários. Além disso, essas duas versóes, pela falta de clareza e de limpidez expressiva que as caracteriza, bem como pelo frequente recurso a vocábulos gregos, não ultrapassavam as dificuldades de tradução próprias da época. A partir do momento em que são criadas novas condiçóes para o ensino do grego, em consonância com a metodologia humanista, Plutarco revela-se de imediato um dos autores cuja obra atrai sobremaneira a intelectualidade italiana. Mas só com a ascensão à ribalta do grande impulsionador do Humanismo florentino de

${ }^{9}$ R. Weiss 1977: 205. 
Quatrocentos, Coluccio Salutati, virá a triunfar aquela que Weiss, em 1955, designava como a new wave. ${ }^{10}$

3. Salutati herdara de Petrarca e de Boccaccio a admiração pelo mundo grego. Não é de estranhar, pois, que a notícia das traduçôes de Plutarco levadas a cabo em Avinhão logo despertasse a sua curiosidade. Satisfazendo os seus anseios, o cardeal Pietro Corsini faz-lhe chegar a versão latina do De cohibenda ira, provavelmente em 1392. Poderemos imaginar a expressão do rigoroso Chanceler florentino quando, ao lançar um ávido olhar para o manuscrito que tanto havia desejado, e que finalmente possuía, depara com um texto escrito num latim confuso e embrulhado, onde as palavras gregas eram tão frequentes, que ele próprio classificou a tradução como "semigrega". Mas a grande solução começa a cintilar-lhe na mente, e eis que póe mãos à versão de Atumano para dela elaborar uma magnífica paráfrase. $\mathrm{O}$ distanciamento do original grego, que, não raro, toca as raias da infidelidade, é compensado pela elegância do seu latim humanista. De toda a forma, trata-se de mais do que uma mera tradução. Com ela, Salutati póe em prática a sua proposta metodológica para a divulgação integrada da cultura grega através da língua latina. Perante a impossibilidade de conseguir traduçóes directas do grego susceptíveis de satisfazerem, em matéria de estilo, as suas exigências de humanista, impunha-se a sobreposição de uma paráfrase correctiva. Aliás, já Boccaccio se propusera

${ }^{10}$ R. Weiss 1977: 6. 
refazer o latim do Homero de Pilato. Salutati tem uma tal confiança nos resultados dessa metodologia, que logo insiste com Antonio Loschi para que a aplique à versão latina da Ilíada levada a cabo pelo mestre de grego do Studium florentino.

Mais problemáticos foram os contactos com Juan Fernández de Heredia destinados a obter o vulgarizamento aragonês. Salutati pretende alargar o seu método a outras áreas linguísticas, propondo-se elaborar, desta feita, uma tradução de aragonês para latim. ${ }^{11}$ Chega a pôr à disposição do Grão-Mestre da Ordem do Hospital a tradução da Odisseia feita por Leonzio Pilato, mas nem assim o consegue demover. É uma vicissitude da história política da época a proporcionarlhe a posse de táo ambicionado texto, do qual a breve prazo se irá, porém, desinteressar. Ao conhecer o anseio do Chanceler florentino, o antipapa Bento XIII, muito empenhado em estabelecer boas relaçóes com a cidade do Arno, logo descortina uma oportunidade de fazer valer a sua pessoa. Coluccio entra no jogo e a Odisseia de Leonzio Pilato parte de imediato para o Antipapa. Entretanto, o vulgarizamento aragonês de Plutarco tarda a chegar a Florença, pondo o Chanceler em cuidados. Finalmente, tem nas mãos o Plutarco aragonês. Estamos em 1395. Salutati rejubila. Mas a rápida evolução dos estudos helénicos levá-lo-á a abandonar, a breve prazo,

${ }^{11} \mathrm{O}$ episódio é documentado pela correspondência referida em R. Weiss 1977: 218-219. Segundo este crítico (1977: 220-22), o texto aragonês, logo que chegou a Florença, foi traduzido para italiano por um anónimo florentino (talvez entre 1395-97), numa versão que granjeou um considerável sucesso. 
o seu método de tradução em cadeia. Um novo capítulo do estudo do grego no Ocidente estava em vias de se iniciar. $^{12}$

Um dos humanistas do círculo de Salutati, Roberto dei Rossi, tivera oportunidade de conhecer em Veneza, no ano de 1390, dois sábios gregos, Demétrio Sídrones e Emanuel Crisolora, de quem recebera algumas liçóes. Quando, de regresso a Florença, dá novas a Salutati acerca desse encontro, o Chanceler logo começa a esboçar um ousado projecto cultural. Por um lado, envia Iacopo Angeli da Scarperia a Constantinopla, a fim de estabelecer contactos com Sídrones e Crisolora. ${ }^{13}$ Angeli parte em 1395 e consegue chegar a Constantinopla, destemidamente, quando a cidade se encontra ameaçada

${ }^{12}$ E. Garin (21970: 51 ss.) considera que a difusão do saber grego, na Itália do século XV, se processa de acordo com três linhas que dizem respeito ao ensino ministrado pelos sábios bizantinos e à sua actividade de produção literária; à formação de um acervo de textos gregos consistente; e à produção dos próprios intelectuais italianos. Assim fica desenhado um percurso que se estende entre o início do magistério de Crisolora, a reunião do Concílio de Ferrara e de Florença em 1438-43, e a chegada do novo fluxo de doutos gregos a Itália na segunda metade do século, depois da queda de Constantinopla. A recepção do legado helénico assumiu profundas reflexóes na discussão dos grandes temas promovida pelos humanistas italianos, caracterizada pela sua viva incidência histórica. Para uma perspectiva geral do Humanismo italiano, valha por todas a referência ao mencionado capítulo de E. Garin ${ }^{2}$ 1970: 5-353. Sobre o contexto florentino, vide, mais recentemente, M. Martelli 1988: 25-201.

${ }^{13}$ Ao longo da estadia de Angeli, Salutati vai sendo informado, por via epistolar, da evolução das conversaçóes com Crisolora, ao mesmo tempo que insiste com o seu emissário a fim de que se esforce por trazer para Florença todos os códices que encontre da obra de Platáo e de Plutarco (R. Weiss 1977: 260). 
pelos Turcos. Por outro lado, Coluccio consegue que o Studium florentino ponha à disposição de Crisolora, que em matéria económica não era pouco exigente, uma cátedra de grego. É assim que, em 1397, Angeli regressa a Florença trazendo consigo Emanuel Crisolora. Salutati vencera de novo.

Com Crisolora, forma-se toda uma geração de humanistas italianos de projecção europeia (Roberto dei Rossi, Angelo da Scarperia, Leonardo Bruni, Poggio Bracciolini, Palla Strozzi, Pier Paolo Vergerio) e inaugura-se uma leccionação que depois virá a ganhar uma certa continuidade, com mestres táo ilustres como Guarino Veronese, Demetrio Scarano, Giovanni Aurispa e Francesco Filelfo. A Florença de Crisolora erige-se em pólo de atracção de grandes intelectuais vindos de outras partes de Itália para aprenderem grego, mas que, da mesma feita, emprestam também o seu lustro à cidade do Arno, tais como Pietro Miani, Ognibene Scola ou o célebre Pier Paolo Vergerio. De outra forma, muitos dos seus alunos, sendo florentinos, irão depois enriquecer o ambiente filo-helénico de outros grandes centros culturais, com relevo não só para a Cúria papal, num período em que as relaçóes entre Roma e Florença, na sua variedade, eram muito intensas, como também para a área véneta, a Lombardia e o reino de Nápoles.

Os elos que ligam o ensino do grego à divulgaçáo da obra de Plutarco não são do foro unicamente linguístico. Crisolora utilizava os seus escritos como manual que servia de base à leccionação, no quadro de um modelo de ensino que veio a ser reproduzido 
pelos seus ilustres discípulos. ${ }^{14}$ Desta feita, a projecção de Plutarco no ambiente do Humanismo florentino só poderá ser cabalmente compreendida em função da excepcional conjugação de uma série de factores: a presença de um mestre de grego que de há muito era declarado admirador da sua obra, e através de cuja mediação chega à cidade do Arno um considerável acervo de originais plutarquianos; a vinculação do ensino do grego aos seus escritos; a receptividade ao magistério do "Educador da Europa", no seio de um contexto político e histórico-literário muito premente; acrescente-se a isto o carácter modelar do Humanismo florentino, que tem por sucedâneo de forma alguma marginal a função atribuída ao exemplo de Plutarco no âmbito de uma campanha de promoção de alcance não só italiano, como também europeu, conforme veremos.

Mas não é Florença a única metrópole onde prosperam os estudos helénicos. Pelo grande palco da Península itálica, vai desfilando uma galeria de doutos bizantinos que faz do mundo grego uma realidade cultural cada vez mais próxima. Jorge de Trebisonda, um grego que desembarcara em Itália na qualidade de mediador para a união das duas Igrejas, descreve um longo e agitado périplo, a partir de 1418, por várias cidades, em algumas das quais lecciona grego, entre Pádua, Veneza, Roma e Nápoles. Por sua vez, Teodoro Gaza, natural de Salónica, chega a Itália em 1440, passando, além do mais, por Pavia, Mântua, Ferrara, em cuja Universidade

${ }^{14}$ Cf. V. R. Giustiniani 1961: 3. 
assumiu a cátedra de grego por três anos, Roma e Nápoles. Mas a personalidade da cultura setentrional que, por esses anos, se destaca de forma conspícua, em virtude da sua notável preparação helénica, é Guarino Veronese. Entre 1403 e 1408, Guarino faz uma estadia em Constantinopla, onde estuda com Crisolora. Valemlhe os estímulos culturais e económicos recebidos do patrício veneziano Paolo Zane, em consonância com um modelo sociológico característico da República. ${ }^{15}$ Quando regressa, póe em prática uma metodologia pedagógica baseada no bilinguismo entre latim e grego que é dimensionada à luz de uma rigorosa perspectiva histórico-filológica. Descreve um longo percurso pelo Centro e pelo Norte de Itália, que o leva por Verona, Florença, Veneza, Ferrara, onde é preceptor de Leonello d'Este, e Pádua. Nos seus bancos, formam-se intelectuais da craveira de Battista Guarini, seu filho (em cuja escola se formará, por sua vez, Aldo Manuzio), Vittorino da Feltre (que desempenhará uma função pedagógica de relevo na Mântua dos Gonzaga), Francesco Barbaro, Leonardo Giustinian ou Andrea Giuliano. Trebisonda e Francesco Filelfo (ou, de outra forma, o marido da culta Teodora Crisolora, filha do célebre mestre de quem Filelfo fora discípulo em Constantinopla entre 1420 e 1422), a partir de um certo momento, circulam em torno da sua figura. Se tivermos em linha de conta, para além disso, que em 1468 é oferecido a S. Marcos de Veneza um fundo constituído por 482 volumes gregos

${ }^{15}$ Sobre o Humanismo veneziano, vide V. Branca ${ }^{2} 1994$ : 194199; e M. Zancan 1988: 619-741. 
e 264 latinos, a dimensão de um quadro que já por si é dotado de vastas dimensôes ainda mais se dilata. Aqui radica um dos fundamentais estímulos do helenismo veneziano. O donatário da Biblioteca Marciana foi o cardeal Bessarion, um grego de Trebisonda nascido em 1403, monge de S. Basílio e arcebispo de Niceia, depois feito Cardeal pelo papa Eugénio IV, o qual revelou grande habilidade diplomática nas conversaçóes para a união das duas Igrejas.

É neste contexto que melhor poderemos compreender, à margem de qualquer tentativa de fácil esquematismo, a direcção prevalentemente formativa e filológica que norteia o estudo de Plutarco em Veneza e na área cultural que lhe é adjacente. $\mathrm{Na}$ verdade, o Humanismo veneziano é apoiado e promovido por um grupo de patrícios dotado não só de um alto sentido de independência moral, como também de uma absoluta autonomia económica. Seu representante prototípico é a figura do intelectual muito ligado à vida prática e dotado de profundas preocupaçóes cívicas, que se reparte entre o estudo das humanae litterae e a administração da res publica. Donde decorre o privilégio conferido ao conteúdo pedagógico da obra de Plutarco, bem como a atenção filológica dedicada ao seu texto, que em breve irá ser dado a conhecer a toda a Europa pelos prelos venezianos.

4. A ampla actividade translativa de Plutarco teve início nos alvores do século XV e sofreu um incremento tal que, porvolta de 1460 , todas as 'Vidas' se encontravam traduzidas, cerca de um quarto delas em mais do que 
uma versão. ${ }^{16}$ De outra forma, o texto dos Moralia colocava espinhosos problemas textuais, pelo que a sua translação se processou a um ritmo mais esforçado. ${ }^{17}$ Daí decorre a precedência cronológica da princeps em original grego dos Moralia, relativamente à das Vitae, amplamente divulgadas através de numerosíssimas versôes.

Cabe a Antonio Cassarino o mérito de ter sido um dos mais perseverantes tradutores dos Moralia da primeira metade do século XV. Siciliano de nascimento, viveu em Constantinopla de 1434 a 1438, onde satisfez uma profunda curiosidade intelectual por Plutarco e por Platão. De regresso a Itália, estabeleceu-se em Génova, onde ensinou grego, tendo concentrado o seu labor não só na tradução dos Apophthegmata Laconica, como também na tradução de mais nove Opuscula. Essas versôes foram muito apreciadas pelo Panormita, que as compilou na sequência da morte de Cassarino, ocorrida em 1447. Mas já anteriormente fora divulgada uma versão dos Apophthegmata Laconica e dos Apophthegmata ad Traianum, elaborada por um outro tradutor de renome, Francesco Filelfo. Os Apophthegmata ad Traianum foram dedicados a Filippo Maria Visconti, exaltando a grandeza do Duque de Miláo ao libertar Alfonso e Giovanni de Aragão, que tinha feito prisioneiros na batalha de Gaeta, travada em Agosto de 1435. Também os tratados de

${ }^{16}$ V. Giustiniani 1961: 6. Neste artigo, encontra-se reunida muita informação sobre as traduçóes das Vitae no século XV.

${ }^{17}$ Podem-se colher muitos dados sobre a difusão dos Moralia nas páginas do trabalho de R. Aulotte 1965, em particular, pelo que diz respeito à Itália, nas pp. 21-26 e 325-343. 
educação moral e cívica despertavam um interesse onde se reflectiam directamente as preocupaçóes pedagógicas características da época. Guarino Veronese, além de ter vertido para latim um considerável número de biografias plutarquianas (de Lisandro e Sila, que dedica ao seu pupilo Leonello d'Este, Sertório e Euménides, Alexandre e César, Díon e Bruto, entre muitas outras), traduziu o De liberis educandis em 1410, tratado que havia de exercer uma decisiva influência sobre a pedagogia humanista, e o De adulatore et amico, que dedicou a Leonello. Mal a arte tipográfica se instala em Itália, logo começam a ser batidos muitos desses Opuscula. Em 1471, o De liberis educandis e os Apophthegmata nas referidas versôes de Guarino e de Filelfo; em 1477, os Problemata, traduzidos por Giovanni Pietro dall'Avenza; em 1479, as Amatoriae narrationes por Poliziano; em 1485, o De civili institutione de Nicolau Sagundino, um grego que viveu em Veneza, o De brevibus clarorum virorum inter se contentionibus de Guarino e o De virtutibus mulierum de Alamanno Rinuccini; e, em 1497, o De virtutibus morum e os Praecepta connubialia de Carlo Valgulio e o De differentia inter odium et invidiam, vertido por mão anónima.

Pelo que diz respeito às 'Vidas', a actividade translativa deu os seus primeiros frutos com algumas décadas de avanço. Uma das primeiras versôes a vir a público teria sido a Vita Bruti, posta em latim pelo embaixador da intelectualidade florentina em Constantinopla, Angeli da Scarperia, em data que ronda o ano de 1400. Esse labor, nos anos subsequentes da sua vida, passados na Cúria romana, alargou-se à Vita 
Ciceronis, à Vita Marii e à Vita Pompei, bem como aos tratados De Alexandri fortuna aut virtute e De Romanorum fortuna aut virtute. Por sua vez, Leonardo Bruni dedica a Salutati a tradução da Vita Antonii antes de partir para Roma, em 1405. Uma tradução que de forma alguma é isolada, já que a ela se devem somar as Vitae de Catão de Útica, Sertório, Pirro, Demóstenes, Cícero e Aristóteles, bem como uma tentativa inconclusa de verter para latim a Vita de Demétrio.

A sua receptividade é emblematizada pela edição romana de 1470, preparada por Giovanni Antonio Campano e batida pelo impressor alemão Ulrich Han, que latinizou o seu nome como Udalricus Gallus. ${ }^{18}$ Tão significativo era o número de traduçóes que circulava em manuscrito, muitas delas de uma mesma Vita, como referimos, que o organizador desta empresa se propóe um objectivo antológico de índole selectiva. O sucesso da edição de Campano é documentado pelo número de reediçóes, cinco no século XV (em Estrasburgo, s. d.; Veneza, 1478, 1491, 1496; e Brescia, 1499),

18 Descrita por V. Giustiniani 1961, fonte das presentes referências. Giovanni Antonio era uma personagem de origem humilde, nascida nos arredores de Caserta em 1429, mas que conseguiu obter uma formação humanista graças ao seu próprio esforço. Frequentou fugazmente as liçóes de grego de Demétrio Calcondila (o mestre de Trissino) em Perugia. Viveu na órbita da Cúria romana, tendo ficado sobremaneira conhecido como autor da biografia de inspiração plutarquiana, Vita et res gestae Bracii Fortebracii. Preparou outros textos para o editor Udalricus Gallus, embora a crítica especializada convenha que nunca conferiu proeminente importância a essa actividade. Vide F. R. Hausmann 1974: 424-429. 
a somar às cerca de duas dezenas que virão à luz no século seguinte (em Veneza, 1502, 1516, 1538; Paris, 1514, 1520, 1521, 1532, 1533, 1557; Brescia, 1524; Basileia, 1531, 1535, 1542, 1547, 1549, 1550, 1553, 1554; e Lyon, 1548, 1552, 1560). ${ }^{19}$ Serviu também de referência a vários vulgarizamentos elaborados em Itália e no estrangeiro. Recorde-se a versão levada a cabo por Battista Alessandro Jaconello da Rieti na boa paz dos Abruzzi, que foi dada aos prelos em 1482, e à qual nos voltaremos a referir; a versão castelhana de Alfonso de Placencia, editada em Sevilha no ano de 1491 por Paulo de Colónia e associados; e a alemá, elaborada por Hieronymus Boner e impressa em Colmar por B. Grieninger em 1541, que teve várias reimpressóes.

De um relance pela edição das Vitae publicada por Campano em 1470, ressaltam à evidência dois factos, o envolvimento de largos sectores da intelectualidade italiana na actividade translativa ${ }^{20}$ e o excepcional relevo que assumem, no plano político, os destinatários em causa. Nas dedicatórias das traduçóes das Vitae, pode ler-se, à transparência, um importante capítulo da história italiana do século XV. É certo que a homenagem prestada por Guarino a Roberto dei Rossi

${ }^{19}$ Apesar disso, em Outubro de 1502 não era possível adquirir uma edição das Vitae no mercado livreiro florentino, dado que todas elas se encontravam esgotadas, tal era a sua procura; cf. infra, n. 36 .

${ }^{20}$ A saber: Alamanno Rinuccini, Antonio Beccaria, Antonio Paccini, Battista Guarino, Donato Acciaiuoli, Francesco Barbaro, Francesco Filelfo, Francesco Zeffi, Iacopo Angeli da Scarperia, Giovanni Aurispa, Giovanni Tortelli, Guarino Veronese, Lapo di Castiglionchio "il Giovane”, Leonardo Bruni, Leonardo Giustiniani e Pellegrino Agli. 
e a Francesco Barbaro com as 'Vidas' de Flamínio e de Díon, respectivamente, ou a dedicatória da biografia de Sertório a Antonio Loschi, por Leonardo Bruni, bem ilustram o alto valor que os humanistas conferiam à amizade. Mas esses nomes diluem-se numa panóplia de figuras muito influentes na política da época, tais como o papa Eugénio IV e vários Cardeais, Luís, rei de França, ou o duque Humphrey of Gloucester, quarto filho de Henrique IV, rei de Inglaterra. Das personalidades mais recorrentemente referidas, contam-se os membros da família Medici. A Cosimo dei Medici são dedicadas a Vita de Temístocles, por Lapo di Castiglionchio "il Giovane", ${ }^{21}$ e a Vita de Timoleonte, por Antonio

21 A biografia de Lapo Castiglione "il Giovane" (Averardo, 1406 ca. - Veneza, 1438) oferece-nos um exemplo paradigmático da função desempenhada pelas dedicatórias das Vitae plutarquianas enquanto instância mediadora na relação entre o intelectual e o poder. Pouco tempo depois da ascensão de Cosimo (1434), Lapo, cuja família não gozava das boas graças dos Medici, dedicalhe a tradução da Vita de Temístocles, na esperança de com ele estabelecer um melhor relacionamento. Perante os escassos resultados da empresa, tenta a sua sorte em meios ligados à Cúria papal, o que o leva a dedicar a Solonis vita ao cardeal Casanova em 1435. Na sequência da morte desse alto dignitário, no ano seguinte, consagra as Vitae de Teseu e Rómulo ao cardeal Prospero Orsini, que muito o desilude, num momento em que Lapo é ameaçado com um processo inquisitorial. Dirige-se entâo a Giovanni Vitelleschi, aquando da sua nomeação como Arcebispo de Florença, consagrando-lhe a Periclis vita. Perdidas as esperanças de suceder a Filelfo no Studium florentino, endereça a Alfonso de Aragão a Fabii Maximi vita. Finalmente, é-lhe oferecido um lugar de leitor na Universidade de Bolonha, ao qual é, porém, forçado a renunciar por razóes de saúde. Entretanto, em Ferrara, é encarregado da tradução dos textos gregos do Concílio, o que lhe vale a proximidade do cardeal Giordano Orsini, homenageado 
Pacini. Piero dei Medici recebe de Donato Acciaiuoli as biografias de Demétrio e de Alcibíades, bem como as Vitae pseudoplutarquianas de Aníbal e de Cipião Africano. Pellegrino Agli, um humanista muito próximo de Ficino, dedica duas biografias pseudoplutarquianas de Homero a Lorenzo dei Medici. O elenco poderia ser alargado com muitas mais referências. Recordemos, além disso, o exemplo de Alamanno Rinuccini que, apesar de não ser propriamente um apoiante da casa de Medici, ofereceu a Cosimo, em 1463, por ocasião da morte do seu filho segundogénito Giovanni, a versão latina da Consolatio ad Apollonium que depois havia de endereçar a Federico da Montefeltro.

$\mathrm{Na}$ verdade, a portentosa fortuna das Vitae de Plutarco na Florença dos Medici assume um claro significado político. ${ }^{22}$ As personagens biografadas representavam, para o público dessa época, retratos ideais

na Publicolae vita, e do cardeal Giuliano Cesarini, a quem dedica a Arati vita. Organizou também um códice antológico com traduçôes das Vitae plutarquianas que circulavam em Itália para o duque Humphrey of Glouscerter (que teria desempenhado um papel importante no âmbito da divulgação das biografias nas Ilhas Britânicas), a quem consagrou, em 1437, a Artaxersis vita. Morre pouco tempo depois, sem nunca ter alcançado a tăo ambicionada integração na Cúria. Bem se pode dizer, pois, que a sua vida foi espelhada pelas versóes das 'Vidas' plutarquianas que elaborou e pelas suas dedicatórias. Lapo traduziu ainda Luciano, Teofrasto, Isócrates, Demóstenes e Xenofonte. Vide R. Fubini 1979: 44-51.

${ }^{22}$ Cf. M. Martelli 1988: 91 ss. Aliás, nas grandes polémicas de índole político-partidária acalentadas ao longo de todo o século $\mathrm{XV}$, a eficácia dos modelos governativos encarnados pelos heróis de Plutarco, bem como as suas interpretaçôes históricas, são intensamente debatidas; vd. E. Garin ${ }^{2} 1970$ : 129-132; e R. Weiss 1977: 269-270. 
de uma integridade cívica absolutae de uma total dedicação ao governo dos povos. Consequentemente, as Vitae respondiam, à perfeição, aos objectivos propagandistas da casa dos Medici, num momento em que se tornava absolutamente necessário justificar a centralização de um poder transmitido por hereditariedade. Mas, para além disso, a dinastia florentina nutria sérias ambiçôes à hegemonia peninsular, pelo que a exaltação da magnanimidade imperial tinha em vista uma intenção especular directamente apontada para as suas figuras de primeiro plano. Assim se compreendeque a encomenda da tradução de biografias plutarquianas a doutos helenistas, pela parte de membros da hierarquia governante, fosse prática corrente. Cosimo era um amante da filosofia que dominava o latim e o grego com elegância, dando menor atenção, pelo contrário, aos poetas em vulgar. $\mathrm{O}$ helenismo respondia muito bem, pois, aos seus ideais de elevação intelectual, indissociáveis do grande sonho de aproximar as várias Itálias. O interesse por Platão e pelos neoplatónicos que o levou a chamar Marsilio Ficino à Villa Careggio ombreava com o incentivo à tradução de Plutarco, enquanto faceta culturalista de um projecto dotado de implicaçóes muito vastas.

Mas uma das características que ainda mais acentua a especificidade do caso florentino diz respeito à abrangência dos grupos sociais implicados, numa diversidade de propósitos que, por vezes, parece tocar as raias do antagonismo. Desde inícios do século XV que a biblioteca do convento de Santa Croce tinha aberto as suas portas a Plutarco, graças à doação feita em 1406 por 
Tedaldo della Casa (o monge franciscano que frequentara as liçóes de Leonzio Pilato) da valorosa colecção de manuscritos que fora compilando e transcrevendo, ao longo de anos e anos. Todavia, mais surpreendente parece ser a receptividade de Plutarco em ambientes onde fermentavam posiçóes críticas em relação aos Medici. É esse o caso da Academia reunida em casa de Alamanno Rinuccini, que se dedicava à sua tradução. ${ }^{23}$ Frequentaram as suas assembleias Andrea Alamanni, Antonio Rossi, Marco Parenti e Donato Acciaiuoli. A adesão à causa mediceia, por parte de muitos intelectuais e de muitas famílias que ocupavam destacados lugares na sociedade florentina, não pressupunha uma conivência de facto. Essa aproximação visava, outrossim, o domínio de posiçóes, no seio da hierarquia instituída, susceptíveis de condicionar a forma como era exercido o poder. Os retratos de Plutarco representavam, para esses sectores, onde também se virá a integrar Maquiavel, um exemplo da grandiosidade e da liberalidade que esperavam caracterizasse o governo da sua cidade, não enquanto monarquia voltada sobre si mesma, mas res publica.

Nesse contexto, quando Lorenzo ascende ao poder, em 1469, dá continuidade ao programa político-cultural dos seus predecessores, mas com uma outra abertura em relação ao vulgar, a qual deixará marcas fortíssimas no Renascimento da cidade mediceia. ${ }^{24} \mathrm{O}$ "Magnifico"

${ }^{23}$ Cf. E. Garin ${ }^{2}$ 1970: 141.

${ }^{24}$ De entre os mais notáveis frutos desse projecto de valorização da língua e das letras florentinas, recordem-se a organizaçáo da Raccolta aragonese, bem como o incentivo ao comentário da obra dos grandes escritores toscanos e à vulgarizaçáo de um significativo 
compreendeu perfeitamente que a hegemonia florentina tinha de passar também pelo plano linguístico e os argumentos com que contava eram de peso - Dante, Petrarca e Boccaccio. É então que tem início um dos grandes capítulos da "età dei volgarizzamenti", para utilizar a feliz expressão de Dionisotti. ${ }^{25}$

A capacidade propulsora do programa linguísticoliterário do "Magnifico" é tal, que o seu exemplo não tardará a erigir-se em modelo que será seguido noutras zonas de Itália. É na sua esteira que deve ser situado o primeiro vulgarizamento de Plutarco que conheceu letra de forma, em $1482 .{ }^{26} \mathrm{O}$ autor da proeza não é uma personagem de grande plano. Battista Alessandro Jaconello da Rieti era um funcionário do Reino de Nápoles que, no último período da sua vida, optara por uma existência calma, no seu retiro de Rieti, em bom convívio com as letras. A sua versão baseia-se na edição romana das Vitae organizada por Campano em 1470. As dificuldades que tem de enfrentar, e das quais revela perfeita consciência, ilustram bem a determinação deste vulgarizador de Plutarco. No prefácio das Vite, Jaconelli

número de textos antigos, muitos dos quais de índole bucólica; vide R. Marnoto 1996: 30-33, 45-47.

${ }^{25}$ Vide o fundamental volume de C. Dionisotti ${ }^{4}$ 1999: 159-161.

${ }^{26} \mathrm{O}$ volume das Vite foi um dos primeiros incunábulos impressos em Aquila pelo tipógrafo alemão Adam von Rothwill. Nele fica contida uma primeira parte das biografias da edição de Campano. Esse vulgarizamento, melhorado e acrescentado, teve sucessivas edições italianas até 1527. Em 1525, Niccolò Zoppino reeditou, em Veneza, o texto de Jaconello e, na mesma data, imprimiu um segundo volume com as restantes biografias vulgarizadas por Giulio Bondone da Padova, também ele posteriormente reeditado. 
não poupa louvores aos Medici e ao seu projecto cultural, sem iludir, porém, os escolhos com que se defronta um vulgarizador que, como ele, maneja uma língua que não fala e que nem táo pouco aprendeu na escola, ou seja, uma língua morta - a língua literária de Dante, Petrarca e Boccaccio. Mas o anseio de divulgar Plutarco a um mais amplo círculo de leitores valia bem tal esforço.

Desta feita, o processo do vulgarizamento de Plutarco situa-se no fulcro do grande bívio do Humanismo italiano. Os ilustres impulsionadores desse movimento, aqueles eruditos detentores de um saber extraordinário, que falavam o latim de Virgílio e o grego de Simónides, visavam também o alargamento dessa cultura a um vasto público. Tal propósito nem sempre era facilmente conciliável, porém, com a devoção que dedicavam às línguas clássicas. A resposta da potência florentina foi a elevação da língua das suas três coroas a veículo literário de comunicaçáo dotado de uma dignidade susceptível de ser colocada em paralelo com a das línguas clássicas. Mas entre o toscano usado por Dante, Petrarca e Boccaccio, por um lado, e a língua falada na Florença dos Medici, por outro, ficava um fosso inquietante, como bem o notara o tranquilo Jaconello.

A proximidade do mundo grego, no âmbito do contexto a que já fizemos referência, levou ainda alguns intelectuais a alimentar o sonho de uma sociedade literária de inspiração helenista. Um dos seus mais requintados frutos, entre finais do século XV e inícios do século XVI, foi a actividade da Academia congregada 
em torno de Aldo Manuzio. Com a impressão da gramática grega de Constantino Lascaris, em 1495, Aldo dá início a uma actividade editorial cuja projecção, ao nível europeu, tem por pressuposto a sólida preparação filológica típica da escola guariniana. Plutarco não podia deixar de figurar, pois, nos seus catálogos. A princeps dos Moralia em original grego saiu dos seus prelos em 1509, com o título de Opuscula, sob o olhar vigilante de Demétrio Ducas, um grego de Creta, e do próprio Erasmo. ${ }^{27}$ Por sua vez, o original das Vitae é batido pelos herdeiros de Aldo Manuzio ${ }^{28}$ em 1519, dois anos depois de ter vindo a público a princeps florentina da bottega Giunta. Apesar da precedência cronológica da giuntina plutarquiana, a crítica especializada reconhece unanimemente o superior apuro da edição aldina. $\mathrm{Na}$ verdade, para além da erudição filológica que subjaz à sua preparação textual, há que ter em linha de conta o

${ }^{27}$ É a partir do seu texto que Erasmo elabora a tradução dos oito Opuscula Plutarchi nuper traducta, Erasmo Roterodamo interprete, editados por Froben em Basileia no ano de 1514 e reimpressos em 1518, a saber, Quo pacto quis dignoscere possit adulatorem ab amico, Quo pacto quis efficere possit ut capiat utilitatem ab inimico, De tuenda bona valetudine praecepta, In principe requiri doctrinam, Cum principibus maxime philosophum debere disputare, Utrum graviores sint animi morbi quam corporis, Num recte dictum sit $\lambda \alpha{ }^{\prime} \theta \varepsilon$

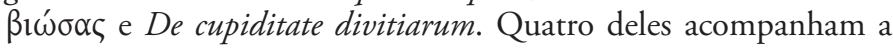
edição da Institutio principis christiani batida pelo mesmo impressor em 1516. Quando os herdeiros de Aldo Manuzio publicam a célebre edição dos opera de Erasmo de 1518, nela incluem não só a tradução erasmiana dos oito Opuscula, como também a de outros três.

${ }^{28}$ A actividade editorial de A. Manuzio situa-se no período cronológico que medeia entre 1494 e 1515, tendo sido posteriormente continuada pelos seus herdeiros. 
precioso acervo de códices plutarquianos a partir do qual foi elaborada - o fundo grego da Biblioteca Marciana de Veneza, cujo núcleo de base se formara graças à doação do generoso cardeal Bessarion. De outra forma, o esforço helenista dos Giunta diluia-se num ambiente que valorizava primordialmente a permeabilidade entre as línguas antigas e o vulgar.

Com Aldo Manuzio, extingue-se a aura de erudição helénica que perpassa pela Itália do Renascimento. A invasão estrangeira parecia iminente, como o prenunciara a conquista do Reino de Nápoles, em 1501, por tropas francesas e espanholas. Para responder a essa ameaça, a Itália tenta solidificar a sua identidade local através do reforço das suas raízes peninsulares, que são latinas.

5. Os caminhos ao longo dos quais toma forma a difusão dos primeiros códices de Plutarco, bem como a sucessiva tradução, vulgarizamento e edição desses textos, coincidem, indissoluvelmente, com os movimentos fulcrais do Humanismo e do Renascimento italianos, acompanhando também os percursos da sua projecção europeia. Tal dado de facto faz-se sinal da fortíssima incidência do seu magistério sobre o tecido cultural italiano, e não só no plano literário, como no plano histórico-político e dos costumes. Daqui decorre uma recepção produtiva caracterizada pela sua extensão aos mais diversos géneros da literatura vulgar e neolatina, cujas linhas gerais nos limitamos a esboçar. 
Para o florescente biografismo renascentista, as Vitae são uma referência que assume claras implicaçóes pragmáticas, em particular no ambiente mediceio, como vimos. Aliás, a valorização das grandes personalidades históricas da cultura florentina, numa galeria de retratos de inspiração plutarquiana, é parte integrante do seu projecto hegemónico. Mas o lastro dessa influência é muito mais vasto, quer em termos cronológicos, quer em termos geográficos. A evolução do protótipo biográfico medieval, centrado na exemplaridade religiosa, para o renascentista, que valoriza a conquista da virtude no plano histórico, tem por grandes modelos, além de Diógenes de Laércio e de Suetónio, Plutarco. Leonardo Bruni escreve, em vulgar, as biografias de Petrarca e de Boccaccio. Matteo Palmieri elabora a Vita Nicolai Acciaiuoli e Bartolomeo Scala compóe a Vita Vitaliani Borromaei. Por ocasiáo de uma viagem a Lucca, Machiavelli redige a Vita di Castruccio Castracani, cuja elaboração lhe sugere reflexóes a partir das quais tirará muitas das inferências acerca da relação entre o governante e o Estado consignadas em Il Principe. ${ }^{29}$ Por sua vez, Gianozzo Manetti (que também biografou o papa Nicolau V, Dante, Petrarca, Boccaccio e Niccolò Nicoli) segue o próprio método de Plutarco, quando coloca em paralelo as vidas de Sócrates e de Séneca. A partir de finais do século XV, começam a ser organizadas grandes sequências de relatos que têm por correspondente a veste

${ }^{29}$ Note-se, no entanto, que, com Machiavelli, o equilíbrio que Plutarco instaurava entre as capacidades de ânimo e a preparação bélica de alguns dos seus mais destacados heróis se desfaz a favor do segundo pólo. 
editorial das Vitae plutarquianas. $\mathrm{Na}$ compilação que Vespasiano da Bisticci intitula, sintomaticamente, Le vite, ficam reunidos 103 quadros. Paolo Giovio organiza várias colectâneas de biografias escritas em latim, parte das quais será vulgarizada por Giovan Battista Gelli. Por sua vez, Giorgio Vasari consagra as Vite de più eccellenti architetti, pittori e scultori italiani da Cimabue insino a' tempi nostri, numa edição de renome europeu.

$\mathrm{O}$ intuito celebrativo de muitos desses relatos anda intimamente associado à voga de Plutarco na historiografia. As referências directas a circunstâncias descritas nas Vitae, ao carácter exemplar das suas personagens, ou às consideraçóes contidas nos Moralia, são uma constante, de Leonardo Bruni a Poggio Bracciolini, Matteo Palmieri, Bartolomeo Scala e Machiavelli.

Outro domínio onde o "Educador da Europa" gozou de um incomensurável prestígio foi o da tratadística moral, pedagógica e dos costumes. Toda a paideia humanista se encontra imbuída pelos grandes ideais plutarquianos. Os seus fundamentos foram consagrados em obras de renome europeu, tais como o De studiis et litteris tractatulus ad Baptistam Malatestam de Leonardo Bruni, o De ingenuis moribus et liberalibus studiis adulescentiae de Pier Paolo Vergerio, ou o De liberorum educatione de Enea Silvio Piccolomini, dedicado a Ladislau "o Póstumo" da Boémia e Hungria. Nas páginas da primeira, Bruni mostra como é possível conciliar harmoniosamente os preceitos da pedagogia helénica com os princípios cristãos, ao passo que um 
dos aspectos mais inovadores de Vergerio consiste na recuperação do valor formativo da retórica clássica na educação do homem completo. Por sua vez, o breve tratado do futuro papa Pio II irá ter uma decisiva influência sobre a concepção do universo da infância. De outra forma, nos Libri della famiglia de Leon Battista Alberti, Plutarco é uma presença tão próxima dos interlocutores, que as normas de conduta e actuaçáo das personagens que biografou se erigem em guia prático para a boa resolução de muitas das questóes em causa. Também os diálogos de Poggio Bracciolini se encontram imbuídos de um moralismo directamente inspirado nos Opuscula. Para além disso, não deverá ser esquecida a prática de insignes mestres, como Guarino Veronese ou Vittorino da Feltre, que, apesar de nunca terem consignado por escrito o seu entendimento da paideia, a orientavam pelos ideais de Plutarco. Mas também nos ambientes palacianos o modelo de comportamento da mesma feita afável e rigoroso proposto pelo "Educador da Europa" alcança um valor exemplar, graças àquela celebérrima gramática do perfeito cortesão que Castiglione dedicou a D. Miguel da Silva, Bispo de Viseu - Il cortegiano. A tradução erasmiana dos Opuscula parece ter tido uma influência decisiva sobre a história do seu texto, em particular pelo que diz respeito à fisionomia da segunda redacção. ${ }^{30}$ Mas, para além disso, ao dissertar sobre a mulher, Castiglione segue um filáo da literatura quinhentista que se desenvolve, $a b$ origine, à sombra da

${ }^{30}$ Vide C. Scarpati 1987: 11-44. Pelo que diz respeito às traduçôes de Erasmo, vide supra, n. 27. 
lição plutarquiana, a tratadística de tema feminino. ${ }^{31}$ Através das páginas de Il cortegiano, Plutarco entra, pois, nas cortes das grandes capitais.

Mas o mais pitoresco sinal da familiaridade das letras italianas com a sua obra será a intersecção da herança literária do escritor helénico, em pleno Renascimento, com a tradição do Duecento e do Trecento, através de processos de contaminatio que desfrutam de particular incidência no campo da novela e dos apotegmas. Florença e a Toscana contam com uma insigne tradição da novela em vulgar, que afunda as suas raízes nas origens românicas, para se estender pelo Novellino, pelo Decameron de Boccaccio, o Novelliere de Sercambi, o Trecentonovelle de Sacchetti e muito para além deles. Nas suas páginas, os exemplos morais convivem com a sátira mordaz ou com a crónica do quotidiano, à luz daquela instância que Bachtin designou como carnavalesca. Quando, no século XV, o gosto pela tirada mordaz se cruza com o filáo novelístico, as histórias breves granjeiam um enorme sucesso. As suas fontes são, da mesma feita, de origem popular ou pseudopopular e erudita. Aqui entronca a recriação das sentenças plutarquianas, juntamente com os Facta et dicta

${ }^{31}$ A atenção dispensada ao modo como Plutarco concebe a mulher teve por fulcro a já referida tradução que foi elaborada por Poliziano em 1479 das Amatoriae narrationes. Essa famosa versão foi integrada na edição dos Opera omnia Angeli Politiani feita em Veneza, por Aldo Manuzio, em 1498, e, mais tarde, foi impressa separadamente em Roma, por Calvo, em 1525. Podem-se colher muitas informaçôes acerca da presença de Plutarco na tratadística quinhentista de tema feminino em M. L. Doglio 1993: 71-100 "Il Capra, i classici e le donne”. 
memorabilia de Valério Máximo, no seio da atmosfera carnavalesca típica da novela. Nas suas Confabulationes, também conhecidas por Facetiae, Bracciolini substitui às notáveis personagens de Plutarco um friso de figuras de extracção popular, ou até socialmente desintegradas, saídas das páginas do Novellino ou do Decameron. Foi também na sua esteira que Alberti compilou os Apologi e Poliziano organizou os Detti piacevoli. Neles se vieram a inspirar Ludovico Carbono e Leonardo, obedecendo, porém, a padróes mais canónicos. Recordem-se ainda, no âmbito da narrativa breve, as fábulas e as pequenas histórias de tema moral relacionadas com o mundo dos animais e com a metamorfose, ora escritas em verso, ora em prosa, quer em latim, quer em vulgar, onde a influência de Plutarco se associa à de Apuleio e de outros autores antigos. A brevidade da sua dimensão e a aparente ocasionalidade da composição de algumas delas não obstam a que sejam assinadas, não raro, por autores de renome - Alberti, Pontano, Firenzuola, Machiavelli.

Se com Guarino Plutarco entra nas escolas, com as Confabulationes de Poggio vagueia pelas ruas das contrade e com Castiglione entra na Corte, é porque o sábio de Queroneia consegue satisfazer as aspiraçóes modelares, da mais diversa ordem, de uma sociedade em férvida evolução.

Neste panorama, a fisionomia editorial dos Opuscula plutarquianos publicados a partir de inícios do século XVI distingue-se perfeitamente da tipologia quatrocentista. À edição de escritos isolados, traduzidos em latim, substitui-se o modelo da colectânea vertida para 
vulgar que é concebida em torno de núcleos temáticos fortes e complementada por índices remissivos. ${ }^{32}$ A reorganização e compilação por topoi responde a exigências de funcionalidade muito prementes na época, ao oferecer ao leitor uma quantidade ingente de informaçóes sistematizadas, que é dizer, prontamente disponíveis para reuso em consonância com as exigências da imitatio.

Plutarco, escritor transtemporal, erige-se definitivamente, na segunda metade do século XVI, num classico moderno, para utilizar aquela fórmula que tão bem caracteriza as escolhas do impressor veneziano Gabriel Giolito dei Ferrari. Giolito compreendeu perfeitamente que o erudito programa editorial de Aldo Manuzio tinha feito a sua época. O seu Plutarco é o Plutarco de massas da Itália quinhentista. Se Aldo possuía uma requintada erudição em matéria de helenismo, a sensibilidade de Giolito ao feed back do mercado livreiro não era menos fina. Em 1565, tem nos seus prelos um vulgarizamento dos apotegmas de Erasmo, essa fantástica compilação onde são reordenados exempla e máximas de grandes autores, cuja consulta e reutilizaçáo são facilitados por copiosos índices. $\mathrm{O}$ editor veneziano compreendeu perfeitamente, pois, que a versão erasmiana elaborada por Giovan Bernardo Gualandi se destinava ao grande público. Por isso mesmo, postos na balança os nomes do sublime Erasmo e do best seller Plutarco, Giolito decide-se pelo segundo. É assim que os Apoftemmi [....]. Motti

${ }^{32}$ Vide o elenco apresentado por R. Aulotte 1965: 340-341. 
arguti e piacevoli e sentenze notabili cosi di principi come di filosofi são impressos, em 1565, como obra de Plutarco. ${ }^{33}$

Por sua vez, o primeiro vulgarizamento das Vite que publica, elaborado por Lodovico Domenichi, sai em 1555 e tem numerosas reediçóes melhoradas nos anos sucessivos (1560, 1566 e assim por diante)..$^{34} \mathrm{Na}$ dedicatória a Guidobaldo II de Urbino, Domenichi lamenta a má qualidade do vulgarizamento que anteriormente circulava no mercado livreiro, numa alusão ao texto preparado por Jaconello e Bondone. ${ }^{35}$ $\mathrm{Na}$ verdade, o vulgarizador quinhentista não era atormentado por aquelas dificuldades linguísticas cuja resolução obrigara o funcionário de Rieti a recorrer a muitos termos dialectais.

A língua de Dante, Petrarca e Boccaccio tinha triunfado, apesar de o sonho hegemónico dos

33 Essa edição é descrita por S.Bongi 1890: 2, 208-209. Só muito recentemente foi apurado tratar-se de uma contrafacção, graças às pesquisas de Paolo Cerchi 1984: 208-225. A atitude de Giolito, ao atribuir a Plutarco um labor que não é da sua pena, tem por contraponto a do Stefano Guazzo que, no tratado La civil conversazione, recolhe numerosos exempla, máximas e sentenças no pseudo-Plutarco de Giolito sem revelar a sua fonte (cf. Quondam 1993: 1, XXXVIII-XXXIX).

${ }^{34}$ Estas edições foram descritas por S. Bongi 1890: 1, 478-479; 2 , 83, 218-219. A partir de 1566, Bongi encontra volumes com datas muito diversas, o que atesta o sucesso editorial do Plutarco de Domenichi. Esse vulgarizamento, que teve na sua base a edição romana de Campano, dominará o mercado até 1772-73, data da publicação, em Verona, da versão elaborada a partir do texto grego por Pompei. Entretanto, foram editados outros vulgarizamentos das Vitae de Campano, com destaque para o de Sansovino, mas que nunca mereceram o apreço do de Domenichi.

${ }^{35}$ Cf. supra, n. 26. 
Medici se ter desfeito. Esse vulgar que harmoniza a relação de um clássico helénico com a esfera de interesses do mundo contemporâneo é o supremo sinal do amadurecimento dos ideais do Humanismo renascentista e da sua incidência geograficamente unitária. Mas é também o seu derradeiro fruto, na medida em que se contenta com as liçóes dos humanistas do século XV. A partir de agora, a cultura italiana dá $o$ Educador à Europa.

6. O carácter pioneiro do papel assumido pelas letras italianas na recuperação da obra de Plutarco, pelo que diz respeito às suas implicaçôes filológicas, translativas e de recriaçáo literária, projectou-se na insigne recepção produtiva dos seus escritos ao longo dos séculos sucessivos, mediante uma linha de continuidade que se estende até aos nossos dias. Não sendo comportável, nos termos deste trabalho, a análise detalhada desse riquíssimo legado, limitar-nos-emos a apontar alguns pontos nodais de significado periodológico.

Quando o fulgor do Renascimento cede o passo à cosmovisão maneirista, Plutarco continua a ser uma referência iniludível em torno da qual tomam forma componentes semântico-formais periodologicamente estruturantes. A orientação crítica à luz da qual se efectua a sua leitura é já prenunciada pelas reservas que Machiavelli coloca ao De fortuna Romanorum, em nome da exaltação das capacidades bélicas e administrativas do povo romano levada a cabo pelo autor dos Discorsi sopra 
la prima Deca di Tito Livio. ${ }^{36}$ De outra forma, o sentido de desengano experimentado por Francesco Vettori, ao confrontar a Roma do seu tempo com a cidade imperial, fundamenta-se, além do mais, na memória de Plutarco. ${ }^{37}$

36 "Molti hanno avuta opinione, ed in tra'quali Plutarco, gravissimo scrittore, che 'l popolo romano nello acquistare lo imperio fosse più favorito dalla fortuna che dalla virtù. Ed intra le altre ragioni che ne adduce, dice che per confessione di quel popolo si dimostra, quello avere riconosciute dalla fortuna tutte le sue vittorie, avendo quello edificati più templi alla Fortuna che ad altro iddio. E pare che a questa opinione si accosti Livio; perché rade volte è che facci parlare ad alcuno Romano, dove ei racconti della virtù, che non vi aggiunga la fortuna. La qual cosa io non voglio confessare in alcuno modo, né credo ancora si possa sostenere. Perché, se non si è trovata mai republica che abbi fatti i profitti che Roma, è nato che non si è trovata mai republica che sia stata ordinata a potere acquistare come Roma. Perché la virtù degli eserciti gli fecero acquistare lo imperio; e l'ordine del procedere, ed il modo suo proprio, e trovato dal suo primo latore delle leggi gli fece mantenere lo acquistato: come di sotto largamente in più discorsi si narrerà." (N. Machiavelli 1971: 146); e cf. supra, n. 29. Desta feita, desenha-se uma linha de continuidade que desenvolve, sob uma nova perspectiva, as implicaçóes plutarquianas das polémicas quatrocentistas; cf. supra, n. 22. Esta orientação crítica não deve de modo algum ser confundida com um decréscimo pelo interesse da sua obra. Na carta que Biagio Buonaccorsi, a 21 de Outubro de 1502, envia de Florença a Machiavelli, para Imola, lamenta não poder satisfazer o seu pedido de remessa das Vitae, que então se encontram esgotadas no mercado livreiro dessa cidade (ibid., p. 1037).

37 "A nocte torno in casa; et ho ordinato d'havere historie assai, maxime de' Romani, chome dire Livio chon lo epitoma di Lucio Floro, Salustio, Plutarcho, Appiano Alexandrino, Cornelio Tacito, Svetonio, Lampridio et Spartiano, et quelli altri che scrivono delli imperatori, Herodiano, Ammiano Marcellino et Procopio: et con essi mi passo tempo; et considero che imperatori ha sopportati questa misera Roma che già fece tremare il mondo, et che non è suta maraviglia habbi anchora tollerati dua pontefici della qualità sono suti e passati.", escreve Vettori na carta que envia a Machiavelli 
$\mathrm{Na}$ tratadística consagrada às grandes questôes de poética e de retórica, o rastro dos seus ensinamentos é vastíssimo. $\mathrm{O}$ uso argumentativo dos pontos de vista defendidos por Plutarco, quer por parte dos neoplatónicos, quer por parte dos seguidores de Aristóteles, ilustra bem o prestígio de que gozava. Mas quando Piero Vettori, nos Commentarii in primum librum Aristotelis de arte poetarum, evoca a sua autoridade para reforçar a fundamental importância do plano expressivo no trabalho literário, em associação com a arte do concetto, rasga já as vias que conduzirão à sua fortuna no período do Barroco. Os seus escritos foram muito valorizados, em particular, nos círculos ligados à Companhia de Jesus, em domínios que vão do diálogo ${ }^{38}$ à biografia. ${ }^{39}$

Ao longo do período do Neoclassicismo, os modelos advogados pelo Educador da Europa voltarão a ter uma profunda incidência sobre a prática pedagógica e a preceituação que lhe é correlata, desta feita mediada pela

a 23 de Novembro de 1513, de Roma (ibid., p. 1158).

${ }^{38}$ Plutarco é um dos modelos explicitamente citados pelo autor do diálogo Observationes circa viventia, quae in rebus non viventibus reperiuntur, o jesuíta Filippo Buonanni. Esta obra, editada em 1691 na cidade papal, ostenta intençóes polémicas em relaçáo a Galileo e, muito particularmente, a Francesco Redi, conforme desde logo o sugere o próprio título, que decalca, latinizando-o, o do célebre tratado rediano Osservazioni intorno agli animali viventi che si trovano negli animali viventi.

39 Embora o biografismo barroco tenda a privilegiar, relativamente ao plano público, o dos conflitos interiores, através de uma aproximação senequiana que teve por grande representante, em Itália, o jesuíta Agostino Mascardi, o rigor e a exactidão de Plutarco preservam o seu carácter exemplar. 
experiência renascentista. ${ }^{40}$ Mas, para além disso, as suas páginas servem de guia a vastos estratos de homens de letras fascinados pelos ideais do mundo antigo. Náo obstante, a necessidade histórica de afirmação das próprias raízes romanas não dá tréguas ao autor do De fortuna Romanorum. Vico, nos Principi di scienza nuova, não hesita em acusá-lo de inveja. ${ }^{41}$

No quadro distanciamento das periodológico

europeu, últimas gerações de escritores

${ }^{40}$ A recriação de Plutarco em sentido moralizante estende-se aos mais diversos géneros literários, através de processos de contaminatio muito abrangentes. É notável o caso da "tragédia a lieto fine" do teatro jesuíta, que funde a grandeza dos heróis plutarquianos com a possibilidade de redenção cristã numa estrutura construtiva de inspiração clássica. Mas, para além disso, não deixem de se recordar, num âmbito mais lato, os grandes heróis da Antiguidade postos em cena pela dramaturgia cortesanesca setecentista, donde decorre uma linha de continuidade que se prolongará pelo século seguinte, espelhando os ideais do Risorgimento.

41 "Però qui è da ammirare la romana gravità e sapienza: che, in queste vicende di stati, i pretori e i giureconsulti si studiarono a tutto loro potere che di quanto meno e con tardi passi s'impropiassero le parole della legge delle XII Tavole. Onde forse per cotal cagione principalmente l'imperio romano cotanto s'ingrandì e durò: perché, nelle sue vicende di stato, proccurò a tutto potere di star fermo sopra i suoi princìi, che furono gli stessi che quelli di questo mondo di nazioni; come tutti i politici vi convengono che non vi sia miglior consiglio di durar e d'ingrandire gli Stati. Così la cagione, che produsse a' romani la più saggia giurisprudenza del mondo (di che sopra si è ragionato), è la stessa che fece loro il maggior imperio del mondo; ed è la cagione della grandezza romana, che Polibio, troppo generalmente, rifonde nella religione de' nobili, al contrario Macchiavello nella magnanimità della plebe, e Plutarco, invidioso della romana virtù e sapienza, rifonde nella loro fortuna nel libro De fortuna Romanorum, a cui per altre vie meno diritte Torquato Tasso scrisse la sua generosa Risposta." (G. Vico 1971: 666-667). 
neoclássicos relativamente a um historicismo que é sentido como cerceador da expressão pessoal não constitui uma novidade. Será sintomático, por consequência, que, no caso italiano, essa viragem se processe, mais do que através da influência de Rousseau, por via plutarquiana. ${ }^{42}$ $\mathrm{Na}$ verdade, ao longo de uma extensa parábola que se estende do Pré-romantismo aos movimentos de fim-deséculo, a permanência do legado clássico reflecte-se no equilíbrio gerado entre o entusiasmo pelas novas formas de percepçáo do mundo sensível e a serenidade da arte grega. Mas a enorme fortuna de Plutarco durante um lapso temporal de tão considerável extensão não pode ser dissociada dos anseios patrióticos que começam a fermentar mais intensamente na sociedade italiana pelos anos da Revolução Francesa e aos quais os valores éticos, heróicos e estéticos propugnados nos seus escritos correspondiam plenamente.

Nas Ultime lettere di Jacopo Ortis de Ugo Foscolo, um texto basilar da narrativa italiana moderna, Plutarco erige-se em perno em torno do qual volteia a conciliação entre a dimensão pública do contado e o plano privado, permitindo aberturas em relação ao comentário histórico-filosófico, às impressôes de viagem, à descrição da natureza e ao domínio metaliterário. ${ }^{43}$ Mas ao Jacopo

${ }^{42}$ Cf. M. Guglielminetti 1986: 874-879. Pelo que diz respeito a Alfieri, cf. infra, n. 46.

43 Essa mediação poderá ser ilustrada pelo passo: “Se m’è dato lo sperare mai pace, l'ho trovata, o Lorenzo. Il parroco, il medico, e tutti gli oscuri mortali di questo cantuccio della terra mi conoscono sin da fanciullo e mi amano. Quantunque io viva fuggiasco, mi vengono tutti d'intorno quasi volessero mansuefare 
Ortis, personagem de papel, que consola o seu desterro com o "divino Plutarco", ${ }^{44}$ anda associado o nome de várias personalidades históricas. ${ }^{45}$ Das masmorras venezianas dos Piombi, Casanova pede que lhe facultem a leitura das Vitae. Em vão, pois os rigorosos carcereiros só admitem obras ascéticas. Massimo Taparelli D’Azeglio tempera o seu retiro de Genzano com Plutarco. Alfieri póe fim, subitamente, ao seu périplo europeu, para se isolar em casa da irmã, onde, com o coração destroçado

una fiera generosa e selvatica. Per ora io lascio correre. Veramente non ho avuto tanto bene dagli uomini da fidarmene cosí alle prime: ma quel menare la vita del tiranno che freme e trema d'essere scannato a ogni minuto, mi pare un agonizzare in una morte lenta, obbrobriosa. Io seggo con essi a mezzodí sotto il platano della chiesa leggendo loro le vite di Licurgo e di Timoleone. Domenica mi s'erano affollati intorno tutti i contadini che, quantunque non comprendessero affatto, stavano ascoltandomi a bocca aperta." (U. Foscolo 1995: 13).

44 "Michele mi ha recato il Plutarco, e te ne ringrazio [...]. Col divino Plutarco potrò consolarmi de' delitti e delle sciagure dell'umanità, volgendo gli occhi ai pochi illustri che quasi primati dell'umano genere sovrastano a tanti secoli e a tante genti. Temo per altro che spogliandoli della magnificenza storica e della riverenza per l'antichità, non avrò assai da lodarmi nè degli antichi, nè de' moderni, nè di me stesso - umana razza!" (ibid.).

${ }^{45}$ A leitura das Vitae na prisão é atitude relativamente comum entre os intelectuais dessa época condenados ao cárcere, quiçá expressáo do intuito de desviar o pensamento, a todo o custo, das contingências do presente para o heroísmo biográfico dos magnânimos retratos de Plutarco. A difusora desta voga teria sido uma mulher, Jeanne-Marie (ou Manon Phlipon) Roland de la Platière (Paris, 1745-1793), uma intelectual apoiante dos girondinos casada com o Ministro do Interior Jean Marie Roland de la Platière. Madame de Roland foi presa a 1 de Junho de 1793 e executada em Novembro do mesmo ano. Na cadeia, escreveu as obras de fundo autobiográfico, Mémoires pour ma fille e Mes dernières pensées. 
pela bela holandesa, procura consolo nas biografias plutarquianas, que elege "libro dei libri", entre gritos e lágrimas. ${ }^{46}$ Aliás, se já Parini associava a eloquência à defesa activa dos grandes ideais cívicos na senda do exemplo do autor das Vitae, De Sanctis vê nos seus heróis o gérmen dos revoltosos napolitanos de $1799 .{ }^{47}$ Por sua vez, nas biografias de Francesco Lomonaco (Vite degli eccellenti italiani e Vite dé famosi capitani d'Italia) e de Francesco Domenico Guerrazzi (Vita di Pasquale Paoli),

46 "Le mie letture erano sempre di libri francesi. Volli leggere l'Eloisa di Rousseau; più volte mi ci provai; ma benchè io fossi di un carattere per natura appassionatissimo, e che mi trovassi allora fortemente innamorato, io trovava in quel libro tanta maniera, tanta ricercatezza, tanta affettazione di sentimento, e sì poco sentire, tanto calor comandato di capo, e sì gran freddezza di cuore, che mai non mi venne fatto di poterne terminare il primo volume. Alcune altre sue opere politiche, come il Contratto sociale, io non le intendeva, e perciò le lasciai. Di Voltaire mi allettavano singolarmente le prose, ma i di lui versi mi tediavano. Onde non lessi mai la sua Enriade, se non se a squarcetti; poco più la Pucelle, perché l'osceno non $\mathrm{mi}$ ha dilettato mai; ed alcune delle di lui tragedie. Montesquieu all'incontro lo lessi di capo in fondo ben due volte, con maraviglia, diletto, e forse anche con un qualche mio utile. L'Esprit di Helvetius mi fece anche una profonda, ma sgradevole impressione. Ma il libro dei libri per me, e che in quell'inverno mi fece veramente trascorrere dell'ore di rapimento e beate, fu Plutarco, le vite dei veri Grandi. Ed alcune di quelle, come Timoleone, Cesare, Bruto, Pelopida, Catone, ed altre, sino a quattro o cinque volte le rilessi con un tale trasporto di grida, di pianti e di furori pur anche, che chi fosse stato a sentirmi nella camera vicina mi avrebbe certamente tenuto per impazzato. All'udire certi gran tratti di quei sommi uomini, spessissimo io balzava in piedi agitatissimo, e fuori di me, e lagrime di dolore e di rabbia mi scaturivano dal vedermi nato in Piemonte ed in tempi e governi ove niuna alta cosa non si poteva né fare né dire, ed inutilmente appena forse ella si poteva sentire e pensare." (V. Alfieri 1965: 74-75).

${ }^{47}$ Cf. A. Battistini 1984: 165-167 e passim. 
as sugestôes plutarquianas incidem quer directamente, quer através da mediação do biografismo renascentista. A “italianização" oitocentista do autor dos Moralia e das Vitae bem poderia ser emblematizada pelo título de duas obras, as Operette morali de Giacomo Leopardi, dadas aos prelos em 1827 e depois, numa segunda versão aumentada, em 1834; e Il Plutarco italiano, com os seus quatro imponentes volumes editados em 1875 , onde fica contida uma panóplia de vidas de italianos ilustres.

No período que medeia entre finais do século XIX e inícios do século XX, a sua obra encontra receptividade no âmbito de um modelo cultural elevado, alheio a intuitos de divulgação. No catálogo Hoepli-Fumagalli de 1892, orientado por critérios de índole marcadamente selectiva, um dos entrevistados, Giuseppe Sergi, recomenda a sua leitura enquanto "utile e gradevole". ${ }^{48}$ Por sua vez, D’Annunzio, no prefácio de La vita di Cola di Rienzo, ${ }^{49}$ advoga energicamente a recuperação

48 "I libri che io vorrei fossero dati per lettura utile e gradevole sono principalmente quelli che si riferiscono alla formazione del carattere, o al consolidamento di esso, che sono suggerimenti dell'attività intellettuale e pratica sotto ogni forma, che inculcano l'indipendenza individuale con rispetto alla legge, che ispirano sentimenti disinteressati, con l'amore verso gli altri nella comunanza sociale e col rispetto dell'altrui personalità. Aggiungo a tali libri quelli che possono educare ai sentimenti estetici, i quali hanno grande influenza sui sentimenti sociali." (apud G. Ragone 1983: 741-742). A lista dos autores cuja leitura é recomendada por este Professor universitário é encabeçada por Plutarco.

49 "Osservato fu già come Plutarco, quando ci dice che Giulio Cesare era magro, di carnagione bianca e molle, soggetto al dolor di testa e al mal caduco, ci tocchi ben più a dentro che con gli 
do interesse biográfico por via plutarquiana, através da valorização da experiência vivida nos seus particulares. Em sua opinião, o significado dessas observações é mais rico do que o das elaboradas reflexôes comparativas das 'Vidas'.

Neste contexto, não será surpreendente o facto de os ecos da obra de Plutarco se estenderem às letras italianas dos nossos dias. Em 1993, foi dada aos prelos, por Giuseppe Pontiggia, uma série de biografias de figuras de ficção que viveram entre os séculos XIX, XX e XXI, sob o título de Vite di uomini non illustri. ${ }^{50}$ Não sendo apresentadas como personagens de excepção, conquanto dotadas de perfis vincados, essas figuras tendem a aproximar-se do horizonte do grande público, o que não será alheio à ampla receptividade do livro,

ingegni de' suoi paragoni. Quando Diogene Laerzio ci racconta che il divino Aristotile usava portar su la bocca dello stomaco un sacchetto di cuoio pien d'olio cotto e che, lui morto, fu ritrovata ne' ripostigli della sua casa gran moltitudine di coppi come in una bottegha di Samo, egli incita la nostra immaginativa ben più che con l'esporci non senza grossezza le dottrine del Peripato. Nelle biografie come nei ritratti noi dunque cerchiamo con avidità e gustiamo con gioia tra i segni della vita particolare quelli che più appaiono dissimiglianti dai comuni, quelli che non concernono se non la singola persona, quelli che di un capitano di un poeta di un mercatante fanno sotto il sole un uomo unico nel genere suo." (G. D’Annunzio 1960: 12). La vita di Cola di Rienzo foi a única biografia, integrada no vasto projecto intitulado Vite di uomini illustri e di uomini oscuri, que D’Annunzio levou a bom termo.

${ }^{50}$ Milano, Mondadori, com reed. G. Pontiggia é também autor de um volume dedicado aos clássicos, no qual ficam contidas várias referências a Plutarco (Pontiggia 1998). Agradeço ao Colega Carmine Ampolo todas as informaçóes fornecidas acerca da presença de Plutarco na actualidade italiana. 
atestada por sucessivas reimpressóes. Mas se, do plano da criação literária, passarmos ao da actividade crítica e editorial, deparamo-nos com um panorama que, nos últimos vinte anos, tem vindo a sofrer uma férvida e profícua evolução. O boletim da secção italiana da Plutarchean Society dá larga notícia dos múltiplos campos de pesquisa que têm vindo a ser persistentemente desbravados. De outra forma, mostra-se muito significativo o interesse despertado pela leitura da obra de Plutarco no seio dos mais diversificados estratos de público. São verdadeiramente notáveis os índices das tiragens das várias ediçōes de escritos breves, não raro excertos dos Moralia, promovidas pelas casas Adelphi e Sellerio, cuja versão é acompanhada, neste último caso, pelo texto original. Quanto às Vitae, encontram-se em circulação duas séries de edições críticas, publicadas pela Mondadori e pela Rizzoli, para além de numerosas ediçôes de divulgação.

7. De entre as poucas informações que se detêm acerca da biografia de Plutarco, ${ }^{51}$ conta-se a de que o autor das 'Vidas' passou alguns anos na Roma imperial, depois do que voltou à pátria Queroneia. Foi dessas mesmas terras itálicas que, na alvorada do Renascimento, a sua obra ganhou nova vida para a cultura da Europa. Um clássico lega-nos valores universais que século após século continuam a brilhar nas constelaçóes do entendimento. ${ }^{52}$ Mas esse legado transtemporal

51 "It is the irony of Fate that of Plutarch, the biographer, there is no biography", comenta F. C. Babbitt 1949: IX .

${ }^{52}$ Muito pertinentes, a este propósito, as palavras de A. Asor 
é inalienável do seu percurso através do tempo uma viagem feita de encontros e de desencontros, de inquietudes e de perplexidades, de partidas e retornos. Também nesta viagem de regresso às terras itálicas fica um pouco da vida de Plutarco.

Rosa 1998: 57: "Il tempo è [...] una componente ineliminabile della costruzione di un sistema dei classici, il fattore dinamico e conflituale, con cui si scontra l'aspirazione dell'auctor a durare, a non essere risucchiato nel grigio gorgo delle innumerevoli identità appena appena formulate, e poi perdute. Il classico vorrebbe fermare per sempre il tempo, ma non può, perché il tempo è in lui e lo muove. E siccome anche il classico è, come tutto nella storia, creatura umana, anch'esso, nonostante la durezza della sua corazza, si muove, e in questo consiste la sua vita". 